\title{
PERTUMBUHAN BIBIT SENGON (Paraserianthes falcataria) PADA BERBAGAI MEDIA TUMBUH
}

\author{
GROWTH OF SENGON SEEDLING (Paraserianthes falcataria) AT VARIOUS GROWTH \\ MEDIA
}

Sukarman, R. Kainde, J.Rombang, dan A. Thomas")

"Fakultas Pertanian Unsrat Manado

\begin{abstract}
This research was carried out in Silviculture Laboratory, Agriculture Faculty, Sam Ratulangi University, from April to June 2012. The aim of this was to examine the influence of growth media combination on height, diameter and number of leaf sengon seedling, using a Randomized Complete Design with one factor. The factor is top soil, top soil and sekam bakar, and top soil and coco peat. Based on the research, the results of Anaslysis of Variance showed that top soil and combination of top soil and sekam bakar give most number of seedling leaf. However, growth of height and diameter at all of combination was no significant, but there was trend that top soil give best growth of height and best growth of diameter given by the top soil and combination of top soil and sekam bakar.
\end{abstract}

Keywords : growth media, sengon

\begin{abstract}
ABSTRAK
Penelitian ini dilaksanakan di Laboratorium Silvikultur, Fakultas Pertanian, Universitas Sam Ratulangi, pada bulan April - Juni 2012. Tujuan dari penelitian ini untuk mengetahui pengaruh kombinasi media tumbuh terhadap pertumbahan tinggi, diameter dan jumlah daun bibit sengon, dengan menggunakan Rancangan Acak Lengkap (RAL) satu faktor. Faktor tersebut adalah tanah lapisan atas, campuran tanah lapisan atas dengan pasir, campuran tanah lapisan atas dengan sekam bakar dan campuran tanah lapisan atas dengan coco peat. Berdasarkan hasil penelitian, bahwa hasil sidik ragam menunjukkan media tumbuh tanah lapisan atas dan media tumbuh campuran tanah lapisan atas dengan sekam bakar menunjukkan pertumbuhan jumlah daun bibit sengon ang terbanyak. Sedangkan pertumbuhan tinggi dan diameter pada berbagai media yang diuji tidak berbeda nyata, tapi kecendrungan pertumbuhan tinggi tanaman terbaik ditunjukan pada media tumbuh tanah lapisan atas dan pertumbuhan diameter terbaik di tunjukkan pada media tumbuh tanah lapisan atas dan campuran tanah lapisan atas dengan sekam bakar.

Kata kunci : media tumbuh, sengon
\end{abstract}

Eugenia Volume 18 No. 3 Desember 2012 


\section{PENDAHULUAN}

Berdasarkan Rencana Kehutanan Tingkat Nasional, bahwa lahan hutan milik pemerintah maupun hutan rakyat harus didorong agar persentasi kontribusinya terhadap pembangunan nasional meningkat sesuai dengan luas lahan hutan itu sendiri. Hal ini dapat diupayakan dengan mengoptimalkan semua fungsi hutan sesuai dengan peruntukkannya. Salah satunya adalah dengan melakukan penanaman kembali lahan-lahan terbuka dan kritis. Menurut Kementerian Kehutanan (2011), luas lahan hutan Indonesia 131.279.115,98 ha dan luas hutan yang kritis $22.025 .581,00$ ha dan sangat kritis sekitar 5.269.260,00 ha.

Sengon merupakan tanaman berhabitus pohon yang mudah beradaptasi dengan kondisi lingkungan yang bervariasi. Akarnya dapat bersimbiosis dengan bakteri rhizobium dan membentuk bintil akar (Andrianto, 2010). Sengon merupakan tanaman intoleran sehingga sesuai untuk mempercepat suksesi penutupan lahan. Menurut Hartanto (2011), daun sengon merupakan pakan ternak yang sangat baik karena mengandung protein tinggi, kayunya banyak diusahakan untuk berbagai keperluan dalam bentuk kayu olahan dengan berbagai peruntukkannya seperti papan mal, mebel sederhana, industri korek api, pensil, papan partikel dan bahan baku idustri pulp kertas, dan lain-lain.

Untuk mengembangkan pembudidayaan sengon perlu ketersediaan bibit yang berkualitas dalam jumlah yang mencukupi. Pertumbuhan bibit yang baik membutuhkan media yang sesuai dengan kebutuhannya. Media tumbuh ialah tempat tumbuh tanaman yang menyediakan unsur hara, udara dan air bagi kebutuhan aktivitas fisiologis dan pertumbuhan tanaman (Anonymous, 2011). Media tumbuh berfungsi sebagai tempat tumbuh dan perkembangan akar serta tempat tanaman mengabsorpsi unsur hara dan air. Jenis dan sifat media tanam berperan dalam ketersediaan unsur hara dan air sehingga berpengaruh terhadap pertumbuhan dan hasil tanaman (Rahmat, 2008 ).

Tanah lapisan atas, pasir, sekam bakar dan coco peat merupakan beberapa media tumbuh yang biasa digunakan untuk media tumbuh tana- man dalam pembibitan. Tanah berfungsi sebagai tempat tumbuh dan berkembangnya perakaran, penopang tegak tumbuhnya tanaman, menyuplai kebutuhan air dan udara, gudang nutrisi seperti senyawa organik, unsur-unsur esensial : N, $\mathrm{P}, \mathrm{K}$, $\mathrm{Ca}, \mathrm{Mg}, \mathrm{S}, \mathrm{Cu}, \mathrm{Zn}, \mathrm{Fe}, \mathrm{Mn}, \mathrm{B}, \mathrm{Cl}$, dan sebagai habitat biota organisme yang berpartisipasi aktif dalam penyediaan hara (Madjid, 2008).

Pasir memiliki kapasitas kelembaban yang sangat rendah dan kandungan hara rendah (Aurum, 2005). Pasir memiliki pori-pori berukuran besar (pori-pori makro) maka pasir menjadi mudah terisi air dan cepat kering oleh proses penguapan. Kohesi dan konsistensi (ketahanan terhadap proses pemisahan) pasir sangat kecil sehingga mudah terkikis oleh air atau angin. Dengan demikian, media pasir lebih membutuhkan pengairan dan pemupukan yang lebih intensif. Hal tersebut yang menyebabkan pasir jarang digunakan sebagai media tanam secara tunggal (Yanuar, 2010).

Sabut kelapa terdiri dari serat dan gabus yang menghubungkan satu serat dengan serat lainnya. Serbuk sabut kelapa (Coco peat) dapat menahan kandungan air dan unsur kimia pupuk serta dapat menetralkan $\mathrm{pH}$ tanah. Media tanam coco peat sanggup menahan air hingga $73 \%$. Dari $41 \mathrm{ml}$ air yang dialirkan melewati lapisan coco peat, yang terbuang hanya $11 \mathrm{ml}$. Derajat keasaman media coco peat 5-8. Sifat tersebut, membuat coco peat dapat digunakan sebagai media yang baik untuk pertumbuhan tanaman hortikultura dan media tanaman rumah kaca (Pramono, 2008). Coco peat mengandung unsur- unsur hara esensial $\mathrm{N} 0,44 \% \mathrm{P}$ 119,1 ppm, K 31718 ppm, dan C organik 5,18\% (Wuryaningsih dan Andiyantoro, 2004).

Sekam bakar merupakan hasil pembakaran tidak sempurna dari sekam padi (kulit gabah). Warna hitam pada sekam bakar akibat proses pembakaran tersebut menyebabkan daya serap terhadap panas tinggi sehingga menaikkan suhu dan mempercepat perkecambahan. Sekam bakar mengandung unsur $\mathrm{N}, \mathrm{P}, \mathrm{K}$ dan Ca masing-masing $0.18 \% ; 0.08 \% ; 0.30 \%$ dan $0.14 \%$ serta unsur $\mathrm{Mg}$ yang besarnya tidak terukur dan mempunyai $\mathrm{pH}$ 6-7 setelah mengalami perendaman selama dua hari. Komposisi sekam bakar terdiri dari $\mathrm{SiO} 2$ (52\%), C (31\%), Fe2O3, K2O, MgO, Cao dan Cu (dalam 
jumlah kecil) sehingga sekam bakar memiliki sifat kimia menyerupai tanah. Porositas yang tinggi dapat memperbaiki aerasi dan drainase media, namun menurunkan kapasitas menahan air pada sekam bakar. Kemampuan menyimpan air pada sekam bakar sebesar $12.3 \%$ yang nilainya jauh lebih rendah jika dibandingkan dengan pasir yang memiliki kapasitas menyimpan air sebesar 33.7\%, (Aurum, 2005).

Karakteristik yang dimiliki ke 4 media tanah lapisan atas, pasir, coco peat dan sabut kelapa di atas dapat dikombinasikan dan saling melengkapi untuk menjadi media tumbuh yang sesuai untuk pertumbuhan bibit sengon. Penelitian ini untuk mencari kombinasi terbaik dari 4 media tersebut.

Penelituan ini bertujuan untuk mengetahui pengaruh kombinasi media tumbuh terhadap pertumbahan tinggi, diameter dan jumlah daun bibit sengon.

\section{METODE PENELITAN}

Penelitian ini dilaksanakan di Laboratorium Silvikultur Program Studi Ilmu Kehutanan Fakultas Pertanian Universitas Sam Ratulangi, Sulawesi Utara. Penelitian ini dilaksanakan pada Maret 2012 - Juni 2012.

Bahan dan alat yang digunakan yaitu pasir, tanah lapisan atas (pasir 62,63\%, debu $16,16 \%$ dan liat $21,21 \%$ ), sekam bakar, coco peat, benih sengon, mistar, kaliper, kamera, poly bag, tally sheet, ember plastik, sekop, gembor penyiraman, timbangan, ayakan ukuran $2 \mathrm{~mm} \times 2 \mathrm{~mm}, \mathrm{pH}$ meter dan kertas asko.

Penelitian yang dilakukan adalah rancangan acak lengkap. Perlakuan yang diuji yaitu perbedaan 4 media tumbuh yang berbeda yaitu $\mathrm{MO}$ : Tanah lapisan atas (top soil), M1 : Tanah lapisan atas dengan Pasir = 1: 1 berdasarkan berat, $\mathrm{M} 2$ : Tanah lapisan atas dengan sekam bakar $=1: 1$ berdasarkan berat, M3 : Tanah lapisan atas dengan coco peat $=1: 1$ berdasarkan berat. Masing-masing perlakuan terdiri dari 5 ulangan, masing-masing ulangan 1 individu tanaman, sehingga total tanaman yang diteliti adalah 20 individu tanaman. Tanaman di naungi dengan paranet (25\%).
Tanah lapisan atas (top soil), pasir, sekam dan coco peat sebelum di campur, terlebih dahulu dilakukan pengayakan dengan ukuran ayakan 2 $\mathrm{mm} \times 2 \mathrm{~mm}$ agar kotoran dan batu-batu terpisah, kemudian bagian yang halus diambil. Setelah dilakukan pengayakan masing-masing media diletakkan pada tempat yang berbeda kemudian dilakukan penimbangan terhadap masing-masing media sesuai perlakuan, setelah itu setiap media di campur merata sesuai campuran media tumbuh yang akan di uji (M0, M1, M2, M3), kemudian media tumbuh di masukkan ke polybag $(12 \mathrm{~cm} \times 16 \mathrm{~cm})$, setiap polybag diberi nomor yang berbeda-beda sesuai dengan campuran media tumbuh dan nomor ulangannya setelah itu polybag di letakkan ke meja penelitian dengan penempatan berjarak ( $25 \mathrm{~cm} \mathrm{x}$ $25 \mathrm{~cm}$ ) sesuai dengan lay out. Setiap hari dilakukan penyiraman pada pagi dan sore hari.

Variabel pertumbuhan yang diamati yaitu tinggi, diameter dan jumlah daun tanaman. Tinggi tanaman diukur $1 \mathrm{~cm}$ dari permukaan tanah sampai ke ujung titik pertumbuhan batang. Diameter batang diukur dengan menggunakan kaliper dalam satuan $\mathrm{mm}$. Pengukuran diameter diukur pada titik $1 \mathrm{~cm}$ dari permukaan tanah. Jumlah daun yang dihitung adalah pertambahan jumlah daun majmuk yang muncul pada setiap pengamatan. Jumlah daun dihitung apabila tangkai daun sudah terlihat jelas, meskipun anak daunnya belum membuka secara sempurna. Nilai pH media tumbuh diukur dengan menggunakan alat $\mathrm{pH}$ meter.

\section{HASIL DAN PEMBAHASAN}

\section{Tinggi dan Diameter Tanaman}

Hasil pengamatan dan analisis ragam terhadap perlakuan media tumbuh tanah lapisan atas (M0), media tumbuh campuran tanah lapisan atas dengan pasir (M1), media tumbuh campuran tanah lapisan atas dengan sekam bakar (M2), dan media tumbuh campuran tanah lapisan atas dengan coco peat (M3) menunjukkan bahwa perlakuan media tumbuh tidak mempengaruhi pertumbuhan tinggi dan diameter bibit sengon secara nyata, hal ini mungkin disebabkan pertumbuhan bibit belum membutuhkan unsur hara yang tinggi, sehingga masih dapat dipenuhi dari lembaga benih dan 
media dengan kandungan unsur hara yang rendah. Hasil pengukuran $\mathrm{pH}$ menujukkan bahwa karakteristik kimia media belum begitu berpengaruh terhadap pertumbuhan bibit sengon sampai umur 2 bulan karena, walaupun media M0 memiliki pH 5,1 masih menujukkan pertumbuhan yang relatif sama dengan media M2 dengan $\mathrm{pH}$ 5,5.

Walaupun demikian dapat dilihat bahwa untuk tinggi tanaman pada pengamatan terakhir (60 HST) yang paling tinggi adalah pada media tanah lapisan atas (M0) sebesar $11,2 \mathrm{~cm}$, sedangkan yang terendah pada media campuran tanah lapisan atas dengan coco peat (M2) sebesar 7,8 cm. Ratarata pertumbuhan tinggi dan diameter tanaman dapat dilihat pada Tabel 1 dan 2.

Kecenderungan pertumbuhan tinggi dan diameter bibit sengon yang terbaik ditunjukkan oleh perlakuan media tumbuh tanah lapisan atas (MO). hal ini terjadi karena media tumbuh tanah lapisan atas (MO) memiliki karakteristik yang baik untuk menujang pertumbuhan bibit sampai umur 2 bulan. Kemampuan menyimpan air yang tinggi dan kemungkinan unsur hara yang tersedia lebih banyak dibandingkan pada media tumbuh campuran tanah lapisan atas dengan pasir (M1) dan media tumbuh campuran tanah lapisan atas dengan sekam bakar
(M2). Sedangkan pada media tumbuh campuran tanah lapisan atas dengan coco peat (M3) pertumbuhan tinggi dan diameter terendah dibandingkan media tumbuh M0, M1 dan M2, hal ini terjadi karena pada media tumbuh campuran tanah lapisan atas dengan coco peat (M3) kemungkinan terkandung senyawa tanin yang berasal dari serbuk sabut kelapa yang merupakan senyawa penghalang mekanis dalam penyerapan unsur hara.

\section{Jumlah Daun}

Hasil analisis ragam menunjukkan bahwa empat perlakuan media tumbuh yang diuji menunjukkan respon jumlah daun bibit sengon secara nyata. jumlah daun bibit sengon tertinggi pada akhir pengukuran (60HST) ditunjukkan oleh perlakuan media tumbuh campuran tanah lapisan atas (M0) dan media tumbuh campuran tanah lapisan atas dengan sekam bakar (M2), dua perlakuan tersebut memiliki jumlah daun yang sama yaitu 9 daun. Sedangkan pada media tumbuh campuran tanah lapisan atas dengan coco peat (M3) menunjukkan respon yang paling rendah terhadap pertumbahan daun tanaman yaitu sebesar 7 daun. Rata- rata jumlah daun bibit sengon dapat di lihat pada Tabel 3.

Tabel 1. Rata-rata Pertumbuhan Tinggi Bibit Tanaman

(Table 1. Average of Seedling Hight Growth)

\begin{tabular}{lcccc}
\hline \multirow{2}{*}{ Perlakuan } & \multicolumn{4}{c}{ Rata-rata Tinggi Tanaman (cm) Pada umur } \\
\cline { 2 - 5 } & 15 HST & 30 HST & 45 HST & 60 HST \\
\hline Tanah lapisan atas (M0) & 3.0 & 6.1 & 7.9 & 11.2 \\
Tanah lapisan atas + Pasir (M1) & 3.0 & 5.2 & 6.6 & 8.8 \\
Tanah lapisan atas + Sekam bakar M2 & 2.9 & 4.8 & 7.1 & 9.9 \\
Tanah lapisan atas + Coco peat (M3) & 3.5 & 5.2 & 6.3 & 7.8 \\
\hline
\end{tabular}

Tabel 2. Rata-rata Pertumbuhan Diameter Bibit Tanaman

(Table 2. Average of Seedling Diameter Plant)

\begin{tabular}{lcccc}
\hline \multirow{2}{*}{\multicolumn{1}{c}{ Perlakuan }} & \multicolumn{4}{c}{ Rata-rata Diameter Tanaman (mm) Pada Umur } \\
\cline { 2 - 5 } & 15 HST & 30 HST & 45 HST & 60 HST \\
\hline Tanah lapisan atas (M0) & 0.7 & 1.0 & 1.4 & 2.2 \\
Tanah lapisan atas + Pasir (M1) & 0.8 & 0.9 & 1.3 & 1.9 \\
Tanah lapisan atas + Sekam bakar (M2) & 0.7 & 1.1 & 1.4 & 2.2 \\
Tanah lapisan atas+ Coco peat (M3) & 0.7 & 0.9 & 1.1 & 1.5 \\
\hline
\end{tabular}


Tabel 3. Rata-rata Jumlah Daun Bibit Tanaman

(Table 3. Average of Number of Leaf Seedling)

\begin{tabular}{lcccc}
\hline \multirow{2}{*}{ Perlakuan } & \multicolumn{4}{c}{ Rata-rata jumlah daun Tanaman Pada Umur } \\
\cline { 2 - 5 } & 15 HST & 30 HST & 45 HST & 60 HST \\
\hline Tanah lapisan atas (M0) & 3 & 6 & 7 & $9 \mathrm{c}$ \\
Tanah lapisan atas + Pasir (M1) & 3 & 4 & 6 & $8 \mathrm{~b}$ \\
Tanah lapisan atas + Sekam bakar (M2) & 3 & 5 & 7 & $9 \mathrm{c}$ \\
Tanah lapisan atas + Coco peat (M3) & 3 & 4 & 6 & $7 \mathrm{a}$ \\
\hline BNT 5\% & \multicolumn{4}{c}{} \\
\hline
\end{tabular}

Ket. Angka yang diikuti oleh huruf berbeda pada kolom yang sama menunjukan jumlah daun yang berbeda nyata menurut uji BNT dengan taraf $5 \%$. HST = Hari setelah tanam.

Pertumbuhan daun berbeda dengan pertumbuhan tinggi dan diameter batang sengon menurut analisis ragam, dimana pertumbuhan tinggi dan diameter tidak berbeda nyata. Menurut Goldsworthy dan Fisher (1996), daun merupakan organ tanaman yang paling dinamis, yang menanggapi terus-menerus perubahan-perubahan praktik budidaya dan keadaan lingkungan. Oleh karena itu, sifat fisik dan kimianya dapat sangat berubah dengan waktu dan dari situasi satu ke yang lain.

Pertumbuhan daun pada media tumbuh tanah lapisan atas (M0) dan media tumbuh campuran tanah lapisan atas dengan sekam bakar (M2) berbeda nyata dengan media tumbuh campuran tanah lapisan atas dengan pasir (M1) dan media tumbuh campuran tanah lapisan atas dengan coco peat, dimana media M0 dan M2 memiliki jumlah daun tertinggi, perbedaan ini terjadi karena pada media tumbuh campuran tanah lapisan atas dengan pasir (M1) kemungkinan ketersediaan unsur hara dan air kurang, sedangkan pada media tumbuh campuran tanah lapisan atas dengan coco peat (M3) menunjukkan pertumbuhan jumlah daun terendah di bandingkan dengan media tumbuh yang lain karena pada media tumbuh $\mathrm{M} 3$ kemungkinan terdapat penghalang mekanis dalam penyerapan unsur hara yaitu senyawa tannin yang berasal dari serbuk kelapa, senyawa tanin ini mengakibatkan daun sengon pada media tumbuh M3 berukuran kecil dan berwarna kekuningkuningan, batang bibit sengon mengalami pertambahan tinggi dan diameter yang lambat. Me- nurut Marisa (1990), senyawa tannin merupakan senyawa penghambat aktivitas hormon giberelin dan menggagu proses transpor unsur hara $P$ dan $\mathrm{K}$, apabila unsur hara ini tersedia dalam jumlah sedikit dan tidak mampu memenuhi kebutuhan pertumbuhan tanaman maka tanaman akan mengalami pertumbuhan akar, batang dan daun yang terhambat (kerdil).

\section{KESIMPULAN DAN SARAN}

Pertumbuhan tinggi dan diameter bibit sengon pada berbagai media tumbuh yang diuji tidak berbeda nyata. Walaupun demikian dapat dilihat bahwa kecendruangan pertumbuhan tinggi bibit sengon yang terbaik adalah yang di tanam pada media tumbuh tanah lapisan atas (M0) dan pertumbuhan diameter tertinggi adalah pada media tumbuh tanah lapisan atas (M0) dan pada media tumbuh campuran tanah lapisan atas dengan sekam bakar (M2).

Pertumbuhan jumlah daun pada berbagai media tumbuh berbeda nyata. Kombinasi media tumbuh yang memberikan pertumbuhan jumlah daun bibit sengon terbaik adalah pada media tumbuh tanah lapisan atas (MO) dan media tumbuh tanah lapisan atas dengan sekam bakar (M2).

Pertumbuhan bibit sengon selama umur 2 bulan belum banyak dipengaruhi oleh karakteristik kimia media.

Agar karakteristik fisik dan kimia media berpengaruh nyata pada pertumbuhan bibit 
sengon, penelitian lanjutan disarankan untuk dilaksanakan sampai bibit sengon berumur 6 bulan.

\section{DAFTAR PUSTAKA}

Andrianto, J. 2010. Pola Budidaya Sengon. Arta Pustaka. Yogyakarta.

Anonymous. 2011. Pratikum Dasar Budidaya Tanaman. http//www.Wordpress.Com. Diakses 1 Mei 2012.

Aurum, M. 2005. Pengaruh Jenis Media Tanam dan Pupuk Kandang Terhadap Pertumbuhan Setek Sambang Colok. Skripsi. Program Studi Agronomi. Fakultas Pertanian. IPB. Bogor. 50 hal.

Goldsworthy dan N.M. Fisher. 1996. Fisiologi Tanaman Budidaya Tropik. Gajah Mada University Press. Yogyakarta. Indonesia.

Hartanto, H. 2011.Cara Pembudidayaan Sengon. Brilliant Book. Yogyakarta.

Kementrian Kehutanan. 2011. Statistik Kehutanan Indonesia. http//dephut.go.id. Diakses 11 Oktober 2012.

Lakitan, B. 2004. Dasar-dasar Fisiologi Tumbuhan. PT. Raja Grafindo Persada, Jakarta.
Madjid, A. 2008. Definisi Tanah, Fungsi dan Profil Tanah. http//www.Dasar-dasar ilmu tanah. blogspot.com. Diakses 10 Maret 2012

Marisa, H. 1990. Pengaruh Ekstrak Daun Pinus (Pinus merkusii Jungh. et de Vriese) terhadap Perkecambahan dan Pertumbuhan Vegetatif Tanaman Kedelai (Glycine max (L.) Merr. Tesis. Pasca Sarjana. Biologi ITB. Bandung.

Rahmat, I. 2008. Pengaruh Media Terhadap Pertumbuhan. http//www. Irfanrahmat.Files. Wordpress.Com. Diakses 20 Maret 2012.

Pramono, J. 2008. Organic Indonesian Vanilla. Tentang Sabut. Diakses Selasa, 11 Januari 2012.

Wuryaningsih dan Andiyantoro. 2004. Media Tumbuh, Kultivar, Dan Daya Hantar Listrik Pupuk Untuk Bunga Potong Anthurium. http:// Wuryan.Wordpress.com. Diakses 7 september 2012.

Yanuar, K. 2010. Ragam Media Tanam. http//www. WordPress.com. Diakses 23 Februari 2012. 
